\title{
PENINGKATAN AKTIVITAS BERBICARA SISWA PADA PELAJARAN BAHASA INDONESIA MELALUI MEDIA AUDIO VISUAL DI KELAS XI IPS 3 SMAN 1 SITIUNG TAHUN PELAJARAN 2016/2017
}

\author{
Hilda \\ Guru SMA Negeri 1 Sitiung \\ Email: hildawahyo11@gmail.com
}

\begin{abstract}
The purpose of this study was to determine whether the students' speaking ability could be improved through Audio Visual media. This research involved students of class XI IPS 3 at SMA Negeri I Sitiung Semester one Academic Year 2016 /2017 and one Indonesian teacher as an observer. The researcher conducted preobservations by interviewing several students and observing the conditions before conducting the study. This research was a continuation to improve students' speaking ability by applying various models. From the results of the preobservations, it was found that the students' speaking ability was not good, so it was necessary to do research. This study consisted of two cycles. In the first cycle, the researcher found that the observation results were not good and the learning process was not effective. Researcher continued research activities in the second cycle. From observations during the second cycle of activities, it can be seen that the students' speaking ability improved better than in the first cycle.

Keywords: speaking ability, audio visual media, Bahasa Indonesia
\end{abstract}

Abstrak

Tujuan penelitian ini adalah untuk mengetahui apakah kemampuan berbicara siswa dapat ditingkatkan melalui media audio visual. Penelitian ini melibatkan siswa kelas XI IPS 3 SMA Negeri I Sitiung semester I Tahun Ajaran 2016/2017 dan seorang guru Bahasa Indonesia sebagai pengamat. Peneliti melakukan observasi awal dengan mewawancarai beberapa siswa dan mengamati kondisi sebelum melakukan penelitian. Penelitian ini merupakan kelanjutan dari peningkatan kemampuan berbicara siswa dengan berbagai model. Dari hasil obeservasi awal diketahui bahwa kemampuan berbicara siswa kurang baik, sehingga perlu dilakukan penelitian. Penelitian ini terdiri dari dua siklus. Pada siklus I, peneliti menemukan hasil obeservasi yang kurang baik dan proses pembelajaran yang kurang efektif. Peneliti melanjutkan kegiatan penelitian pada siklus kedua. Dari pengamatan selama siklus II, terlihat bahwa kemampuan berbicara siswa meningkat lebih baik dari siklus I.

Kata kunci: Aktivitas berbicara, media audio visual, Bahasa indonesia

\section{PENDAHULUAN}

Pembelajaran bahasa Indonesia di sekolah sekarang ini menuntut tujuan komunikatif dan mencakup empat keahlian yaitu mendengar, berbicara, membaca, dan menulis. Namun, kenyataan di lapangan yang terjadi justru kemampuan siswa dalam berbahasa Indonesia, baik lisan maupun tulisan, masih jauh dari yang 
diharapkan. Hal ini dibuktikan dengan masih banyaknya siswa yang kurang mampu berkomunikasi, terutama secara lisan, seperti menjawab pertanyaan sederhana, dan menyampaikan maksud meskipun sudah belajar bahasa Indonesia secara formal selama bertahun-tahun.

Penulis mengalami kesulitan dalam pembelajaran bahasa Indonesia karena masih banyak siswa yang pasif, tidak mau berpartisipasi, dan malu berbicara, bertanya dan menjawab dalam bahasa Indonesia. Hal ini disebabkan oleh beberapa faktor, yaitu faktor dari guru, siswa dan lingkungan belajar. Dari semua faktor di atas tergambar jelas bahwa permasalahan berbicara dalam kelas adalah permasalahan yang terjadi hampir di semua kelas dalam pembelajaran bahasa Indonesia, dan sangat perlu ditemukan cara atau strategi yang tepat. Salah satu media yang menarik minat siswa untuk berbicara adalah dengan menggunakan media audio visual. Penulis menggunakan media audio visual untuk meningkatkan aktivitas siswa dalam berbicara karena media ini sangat mudah menarik minat dan perhatian siswa di dalam kelas, sehingga siswa menjadi termotivasi untuk berbicara.

\section{Pengertian Aktivitas Belajar}

Menurut Djamarah (2001) aktivitas belajar adalah suatu tindakan yang melibatkan fisik maupun psikis pada diri seseorang untuk mencapai suatu tujuan yaitu tujuan belajar. Aktivitas belajar yang efektif melibatkan seluruh kemampuan siswa dalam menggunakan inderanya.Semakin banyak indera yang terlibat, maka semakin banyak kegiatan pembelajaran yang diperoleh. Paul B Diedrich dalam Sardiman (2004) membagi aktivitas sebagai berikut;

1. Visual Activities, yang termasuk didalamnya misalnya membaca, memperhatikan gambar dan demonstrasi

2. Oral Activities, seperti; menyatakan, merumuskan, bertanya, memberi saran, mengeluarkan pendapat, mengadakan wawancara

3. Listening Activities, contohnya mendengarkan uraian, percakapan, diskusi dan music.

4. Writing Activities, seperti menulis cerita, laporan dan angket.

5. Drawing Activities, misalnya menggambar, membuat grafik, peta, diagram

6. Motor Activities, seperti melakukan percobaan, membuat konstruksi, mereparasi, bermain, berkebun, beternak.

7. Mental Activities, sebagai contoh misalnya mengingat, memecahkan masalah, menganalisis, mengambil keputusan.

8. Emotional Activities, misalnya menaruh minat, merasa bosan, gembira, bersemangat, berani, gugup.

\section{Pengertian Berbicara}

Berbicara adalah kemampuan mengucapkan bunyi-bunyi artikulasi atau kata-kata untuk mengekpresikan, menyatakan serta menyampaikan pikiran, gagasan, dan perasaan. Berbicara sangat penting dalam berkomunikasi, berbicara dilakukan setiap hari dalam kehidupan baik dalam lingkungan keluarga maupun masyarakat. Kamus Besar Bahasa Indonesia Poerwadarminta (1996) tertulis bahwa berbicara adalah berkata, bercakap, berbahasa atau melahirkan pendapat (dengan perkataan, tulisan dan sebagainya) atau berunding. 
Menurut Tarigan, (1998) memberikan batasan bahwa berbicara adalah kemampun mengucapkan bunyi-bunyi artikulasi atas kata-kata untuk mengekspresikan, menyatakan serta menyampaikan pikiran, gagasan dan perasaan. Sedangkan sebagai bentuk atau sebagai wujudnya berbicara disebut sebagai suatu alat untuk mengkomunikasikan gagasan-gagasan disusun serta dikembangkan sesuai dengan kebutuhan-kebutuhan sang pendengar atau penyimak.

\section{Pengertian Media Pembelajaran}

Kata media secara harfiah berarti perantara atau pengantar.Suyanto (2005) mengemukakan bahwa media adalah suatu sarana yang digunakan untuk menyampaikan pesan dari seorang komunikator kepada komunikan. Heinich (1996) dan kawan-kawan mengartikan media sebagai perantara yang mengantar informasi dari sumber kepada penerima. Dengan demikian televisi, radio, film, foto, bahan cetakan, rekaman, dan sejenisnya adalah tergolong media.Apabila media tersebut membawa informasi atau pesan-pesan yang mengandung maksud dan tujuan pengajaran maka media itu disebut media pembelajaran.

\section{Media Visual}

Levie dan Lents sebagaimana dikutip oleh Sutirman (2013) mengemukakan empat fungsi media pembelajaran, khususnya media visual, yaitu fingsi atensi, afektif, kognitif dan kompensatoris. Fungsi atensi media visual merupakan inti, yaitu menarik dan mengarahkan perhatian siswa untuk berkonsentrasi kepada isi siswaan yang berkaitan dengan makna visual yang ditampilkan. Media gambar yang diproyeksikan melalui LCD dapat memfokuskan dan mengarahkan perhatian siswa kepada materi yang ditayangkan. Hal ini berpengaruh terhadap peningkatan aktivitas berbicara siswa dalam kelas.

\section{METODOLOGI PENELITIAN}

Penelitian tindakan kelas ini dilaksanakan di SMA Negeri 1 Sitiung untuk mata pelajaran Bahasa Indonesia. Penelitian ini dilaksanakan pada tahun ajaran 2016-2017, yaitu pada semester satu di bulan Oktober dan November tahun 2016. Dalam penelitian ini yang menjadi subjek penelitian adalah siswa kelas XI IPS 3 SMAN 1 Sitiung yang berjumlah 30 orang.

Penelitian tindakan kelas ini dilaksanakan melalui dua siklus yang meliputi empat tahap yakni:

a. Tahapan siklus I: perencanaan, pelaksanaan, pengamatan dan refleksi.

b. Tahapan siklus II: merupakan siklus lanjutan dari siklus satu yang sudah direncanakan perbaikannya.

Untuk lebih jelasnya dapat dilihat pada uraian di bawah ini:

a. Perencanaan

2) Guru akan memotivasi, apersepsi dan menyampaikan tujuan pembelajaran. Siswa akan dibagi dalam kelompok kecil yang terdiri empat-lima orang.

3) Guru memutar video pendek dan menyuruh siswa untuk mencatat nama tokoh dan penokohan, tema, latar, amanat, konflik, dan mengaitkan dengan kehidupan sehari-hari. 
4) Siswa menyiapkan catatan kecil tentang apa yang dilihat di video. Guru memberikan kesempatan kepada siswa secara kelompok untuk bertanya tentang hal yang belum jelas. Guru akan memutarkan video dalam pembelajaran

5) Guru akan menghentikan pemutaran video di dua menit terakhir dan menyuruh siswa untuk menebak dan mendiskusikan akhir cerita. Guru akan mengamati aktivitas berbicara siswa.

6) Guru akan membuat catatan pribadi

b. Pelaksanaan

Semua kegiatan yang direncanakan dapat dilaksanakan dalam pembelajaran. Guru selaku peneliti langsung melaksanakan tindakan sesuai dengan apa yang sudah direncanakan dalam tahap perencanaan penelitian. Peneliti dalam melaksanakan tindakan penelitian menggunakan media video pendek dalam meningkatkan aktivitas berbicara siswa.

c. Pengamatan

Pengamatan dilakukan oleh peneliti itu sendiri dan dibantu oleh observer atau kolaborator dengan mengisi instrumen yang telah disediakan. Dalam tahap pengamatan, observer akan menggunakan instrument yaitu berupa lembar observasi untuk mencatat peningkatan keaktifan siswa berbicara menggunakan media video pendek. Observer mengamati dengan seksama pelaksanaan pembelajaran dan mengisi lembar observasi selama proses penelitian. Observer mengamati dan mengisi lembar observasi dengan jujur dan objektif.

d. Refleksi

Refleksi akan dilakukan oleh peneliti bersama-sama dengan kolaborator untuk melihat proses pembelajaran di kelas bahasa Indonesia melalui media video pendek. Dalam tahap ini peneliti dan observer membahas tindakan selanjutnya. Apakah peneliti perlu untuk melakukan perencanaan ulang atau tidak.

\section{HASIL PENELITIAN DAN PEMBAHASAN Deskripsi Kondisi Awal}

Kondisi awal di kelas XI IPS 3 SMA Negeri I Sitiung dalam berbicara pada mata pelajaran Bahasa Indonesia adalah banyak siswa yang pasif, dan masih malu berbicara. Hal ini disebabkan antara lain materi yang kurang menarik minat siswa dan penggunaan media pembelajaran yang masih sangat terbatas. Hasil praobservasi di kelas XI IPS 3 menunjukkan siswa yang aktif berbicara hanya 7 orang. Dari data ini dapat disimpulkan bahwa keaktifan siswa XI IPS 3 adalah sebanyak $23 \%$.

\section{Hasil Penelitian}

\section{Siklus Pertama}

\section{a. Perencanaan}

1) Guru akan memotivasi, apersepsi dan menyampaikan tujuan pembelajaran. Siswa akan dibagi dalam kelompok kecil yang terdiri empat - lima orang.

2) Guru menyampaikan bahwa akan diputarkan video pendek dan menyuruh siswa untuk mencatat tema, nama tokoh dan penokohannya, alur cerita, konflik, amanat, dan mengaitkannya dengan kehidupan sehri-hari. 
3) Siswa menyiapkan catatan kecil tentang apa yang dilihat di video. Guru memberikan kesempatan kepada siswa secara kelompok untuk bertanya tentang hal yang belum jelas.

4) Guru akan memutarkan video dalam pembelajaran. Guru akan menghentikan pemutaran video di dua menit terakhir dan menyuruh siswa untuk menebak dan mendiskusikan akhir cerita.

5) Siswa akan memerankan akhir cerita dan meminta mengaitkan isi cerita dengan kehidupan sehari-hari. Guru akan mengamati aktivitas berbicara siswa. Guru akan membuat catatan pribadi

\section{b. Pelaksanaan}

Pelaksanaan pada siklus pertama penelitian tindakan kelas, guru melakukan beberapa tindakan yaitu:

1) Guru memotivasi, apersepsi dan menyampaikan tujuan pembelajaran. Menjelaskan rencana kegiatan saat itu, yaitu menonton video pendek "Biduak"

2) siswa disuruh menebak akhir cerita dan mengaitkan cerita dengan kehidupan yang terjadi sehari-hari. Setelah itu siswa diminta untuk duduk berkelompok. Siswa dibagi dalam kelompok kecil yang terdiri empat - lima orang. Pembagian kelompok dilakukan berdasarkan tempat duduk. Jadi kelompok diskusi berdasarkan tempat duduk yang terdekat. Guru memberikan kesempatan kepada siswa secara kelompok untuk bertanya tentang hal yang belum jelas

3) Guru memutarkan video "Biduak" pada siklus pertama. Guru menyampaikan hal yang harus dilakukan siswa yaitu mengidentifikasi tema, tokoh dan penokohannya, alur, konflik, latar, amanat, dan mengaitkan cerita dengan kehidupan sehari-hari, dan memerankan akhir cerita dengan kelompok mereka. Guru membuat catatan pribadi. Guru dan kolaborator mengamati aktivitas siswa.

\section{c. Hasil}

Siklus pertama dilaksanakan dalam dua kali pertemuan, dan dari lembar observasi peneliti dapat mengemukakan bahwa pada siklus pertama didapatkan data sebagai berikut: dari jumlah tujuh kelompok diskusi siswa, terdapat dua kelompok yang aktif berbicara dan bersemangat dalam berdiskusi dalam kelompoknya. Lima kelompok diskusi yang lainnya masih pasif. Beberapa siswa terlihat mencoret-coret kertas dan melamun.

Kegiatan pembelajaran pada siklus pertama di pertemuan pertama belum terlihat keaktifan siswa secara signifikan. Siswa hanya aktif secara visual dengan melihat tayangan video saja. Pada saat menebak akhir cerita dan mengaitkan cerita dengan kehidupan sehari-hari, sebagian siswa masih terlihat melakukan aktivitas lain dalam kelompoknya. Pada pertemuan kedua di siklus pertama terjadi peningkatan keaktifan siswa menjadi tiga kelompok diskusi atau $43 \%$ telah aktif untuk berbicara dalam kelompok dan menampilkan peran akhir cerita menurut versi kelompok mereka. Untuk lebih jelasnya dapat dilihat pada tabel dibawah ini:

Tabel 1. Aktivitas Berbicara Bahasa Indonesia Siklus 1

\begin{tabular}{llcc}
\hline No. & Aktivitas yang diamati & Frekuensi & Persentase \\
\hline 1. & Melihat tayangan Video & 25 & $83 \%$ \\
2. & Mengemukakan pendapat dalam kelompok & 10 & $33 \%$ \\
\hline
\end{tabular}




\begin{tabular}{llcl}
\hline 3. & Menyampaikan laporan & 7 & $23 \%$ \\
4. & Ikut serta memainkan peran & 12 & $40 \%$ \\
5. Mendengar pendapat teman & 13 & $43 \%$ \\
6. & Menebak akhir cerita & 13 & $43 \%$ \\
7. & Menaruh minat & 16 & $53 \%$ \\
\hline
\end{tabular}

\section{d. Refleksi}

Dari siklus pertama, setelah dilakukan analisa terhadap hasil observasi catatan harian dan wawancara singkat terhadap siswa dan diskusi dengan kolaborator maka diperoleh hasil berikut: siswa sudah terlihat aktif melihat video pendek, namun dalam mengidentifikasi tokoh, latar, menebak akhir cerita serta memerankan akhir cerita dan mengaitkan cerita dengan kehidupan sehari-hari masih ada beberapa kelompok yang masih belum aktif semua anggotanya. Beberapa anggota kelompok tersebut masih terlihat melamun, mencorat-coret kertas, membicarakan hal lain diluar pelajaran Bahasa Indonesia, dan beberapa siswa hanya diam mendengarkan teman mereka.

Dengan demikian, peneliti berdiskusi dengan kolaborator dan menentukan tindakan selanjutnya yaitu memotivasi siswa untuk lebih terlibat dalam kelompoknya. Selanjutnya, guru mengumumkan bahwa kelompok yang akhir ceritanya yang paling mendekati cerita yang sebenarnya menjadi pemenang dan akan memperoleh hadiah. Kelompok yang tidak aktif akan mendapatkan hukuman yang diberikan oleh kelompok yang menang. Jadi sebelum melanjutkan ke siklus kedua, peneliti menyampaikan kepada seluruh siswa untuk mempersiapkan jenis hukuman apabila mereka menang, dan mempersiapkan diri seandainya mereka kalah.

\section{Siklus Kedua}

\section{a. Perencanaan}

1) Guru memotivasi, apersepsi dan menyampaikan tujuan pembelajaran

2) Menjelaskan rencana kegiatan saat itu, yaitu menonton video pendek "Dia Bukan Segalanya" dan siswa disuruh menebak akhir cerita dan mengaitkan cerita dengan kehidupan sehari-hari. Setelah itu siswa diminta untuk duduk berkelompok.

3) Siswa dibagi dalam kelompok kecil yang terdiri empat - lima orang. Pembagian kelompok dilakukan berdasarkan tempat duduk. Jadi kelompok diskusi berdasarkan tempat duduk yang terdekat. Guru memberikan kesempatan kepada siswa secara kelompok untuk bertanya tentang hal yang belum jelas. Guru memutarkan video pendek " Dia Bukan segalanya" pada siklus kedua.

4) Guru menyampaikan hal yang harus dilakukan siswa yaitu menebak akhir cerita, mememerankan akhir cerita, dan mengaitkan cerita dengan kehidupan sehari-hari. Guru membuat catatan pribadi. Guru dan kolaborator mengamati aktivitas siswa.

\section{b. Pelaksanaan}

Guru melakukan seluruh kegiatan perencanaan sesuai yang direncanakan. Guru memotivasi, apersepsi dan menyampaikan tujuan pembelajaran. Kegiatan inti yaitu menonton video pendek "Biduak". Peneliti melakukan pembelajaran di bantu observasi oleh observer. Pada saat kegiatan penutup, peneliti melakukan penilaian dan menyimpulkan materi pembelajaran bersama - sama dengan peserta didik. 


\section{c. Hasil}

Dari lembar observasi peneliti dapat mengemukakan bahwa pada akhir siklus kedua didapatkan data sebagai berikut: dari tujuh kelompok diskusi siswa lima kelompok sudah ikut berpartisipasi, tetapi terdapat dua kelompok yang beberapa anggotanya belum aktif berdiskusi tentang akhir cerita dan mengaitkan cerita dengan kehidupan sehari-hari. Jadi siswa yang aktif pada pertemuan pertama adalah $71 \%$. Kegiatan pembelajaran pada siklus kedua di pertemuan kedua sudah terlihat keaktifan siswa secara signifikan. Sebagian besar siswa telah melakukan aktivitas seperti ikut mengidentifikasi tema, tokoh dan penokohan, latar, amanat, konflik dan mengaitkan cerita dengan kehidupan sehari-hari dalam video pendek. Siswa terlihat bersemangat dan ceria dalam pembelajaran. Pada pertemuan kedua di siklus kedua terjadi peningkatan keaktifan siswa menjadi enam dari tujuh kelompok diskusi atau $86 \%$ telah aktif berbicara. Untuk lebih jelasnya dapat dilihat pada tabel dibawah;

Tabel 2. Aktivitasberbicara siswa dalam Bahasa Indonesia Siklus 2

\begin{tabular}{llcc}
\hline No. & \multicolumn{1}{c}{ Aktivitas yang diamati } & Jumlah & Persentase \\
\hline 1. & Melihat tayangan Video & 30 & $100 \%$ \\
2. & Mengemukakan pendapat dalam kelompok & 23 & $77 \%$ \\
3. & Menyampaikan laporan & 15 & $50 \%$ \\
4. & Ikut serta memainkan peran & 26 & $87 \%$ \\
5. & Mendengar pendapat teman & 24 & $80 \%$ \\
6. & Menebak akhir cerita & 26 & $87 \%$ \\
7. & Menaruh minat & 28 & $93 \%$ \\
\hline
\end{tabular}

\section{d. Refleksi}

Dari siklus kedua, pertemuan pertama dan kedua setelah dilakukan analisa, terhadap hasil observasi catatan harian dan wawancara singkat terhadap siswa dan diskusi dengan kolaborator maka diperoleh hasil berikut: siswa sudah aktif dalam berbicara bahasa Indonesia dan sangat bersemangat dalam menebak akhir cerita, memainkan peran mereka masing-masing dan mengaitkan cerita dengan kehidupan sehari-hari. Perbandingan presentase keaktifan siswa dalam siklus pertama dan kedua dapat dilihat pada grafik berikut:

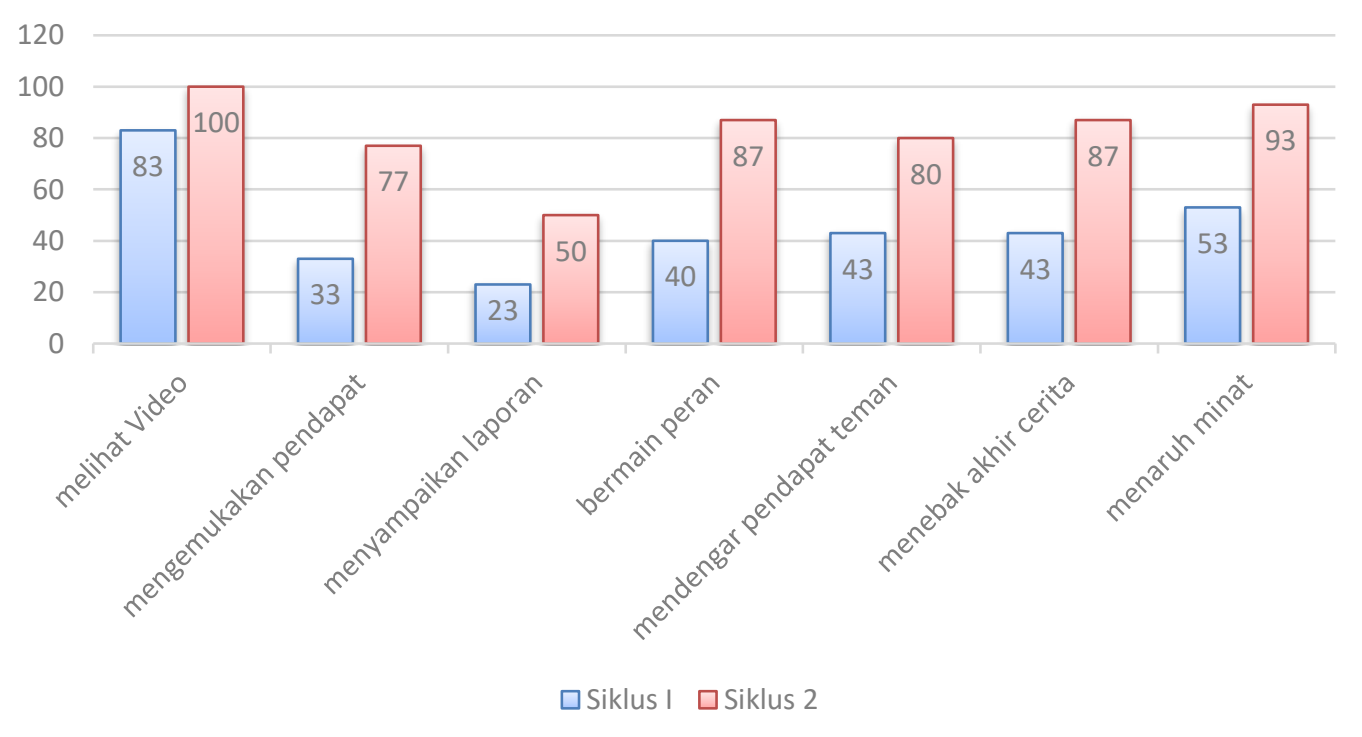

Grafik 1. Nilai perbandingan presentase keaktifan siswa dalam siklus pertama dan siklus kedua. 
Berdasarkan grafik diatas dapat terlihat bahwa aktivitas belajar bahasa Indonesia siswa menunjukkan peningkatan yang signifikan dan sangat memuaskan. Beberapa aktivitas mengalami peningkatan terutama pada aktivitas bermain peran sebesar $87 \%$ dan mengemukakan pendapat sebesar $77 \%$.

\section{PENUTUP}

\section{SIMPULAN}

Peneliti menyimpulkan bahwa dengan menggunakan media Short Videos dalam pembelajaran berbicara, keaktifan siswa meningkat secara signifikan. Aktivitas siswa melihat tayangan video meningkat menjadi 100\%, mengemukakan pendapat dalam kelompok sebesar 77\%, menyampaikan laporan sebesar $50 \%$, ikut serta memainkan peran sebesar $87 \%$, mendengar pendapat teman sebesar $80 \%$, menebak akhir cerita sebesar $87 \%$ dan menaruh minat sebesar 93\%. Dengan demikian, aktivitas berbicara siswa dalam pembelajaran bahasa Indonesia secara umum meningkat setelah menggunakan media Short Videos.

\section{SARAN}

Peneliti menyarankan untuk menerapkan Media Short Videos dalam Pembelajaran Bahasa Indonesia supaya aktivitas berbicara siswa meningkatkan. Peneliti juga menyarankan kepada rekan - rekan guru untuk terus melakukan perbaikan model dan strategi pembelajaran.

\section{DAFTAR PUSTAKA}

Djamarah. 2001. Motivasi Belajar Mengajar. Rennika Cipta: Jakarta Hamalik, Oemar. 2001. Pengantar Evaluasi Pendidikan Tarsito: Bandung Haryadi dan Zamzani. 2000. Peningkatan Keterampilan Berbahasa Indonesia. Jakarta: Departemen Pendidikan dan Kebudayaan Direktorat Jenderal Pendidikan Tinggi.

Poerwadaminta. 1996. Teknik Evaluasi Pendidikan. Tarsito: Bandung.

Resmini, Novi. Juanda, Dadan. 2008. Pendidikan Bahasa dan Sastra Indonesia di Kelas Tinggi. Bandung: UPI Press.

Resmini, Novi. Juanda, Dadan. 2009. Pembinaan Dan Pengembangan Pembelajaran Bahasa Dan Sastra Indonesia. Bandung: UPI Press.

Rofiudin, A. Zuhdi, D. 2001. Pendidikan Bahasa dan Sastra Kelas Tinggi. Jakarta: Depdikbud.

Roestiyah. 2001. Strategi Belajar Mengajar. Jakarta: Rineka Cipta.

Sardiman. 2004. Interaksi dan Motifasi Belajar Mengajar. Jakarta: PT Grafindo

Sofian. 2010. Pemanfaatan Media Video untuk Meningkatkan Motivasi Belajar Siswa di MAN 3 Jambi. Makalah Jurusan Kurikulum dan Teknologi Pendidikan.

Sukri. 2014. Video Sebagai Media Pembelajaran. Lsd.telkomuniversity.ac.id

Sutirman. 2013. Media dan Model Pembelajaran. Graha Ilmu: Yogyakarta.

Suyanto. 2001. Proses Belajar Mengajar. Rinneka Cipta: Jakarta.

Tarigan, Henry Guntur. 1983. Berbicara Sebagai Suatu Keterampilan Berbahasa. Bandung: Angkasa.

Tarigan. 1998. Keterampilan Berbicara. Angkasa: Bandung.

Wendra, I Wayan. 2009. Buku Ajar Keterampilan Berbicara. Singaraja: Universitas Pendidikan Ganesha. 